\title{
Endemism analysis of Neotropical Pentatomidae (Hemiptera, Heteroptera)
}

\author{
Augusto Ferrari ${ }^{1}$, Andressa Paladini ${ }^{2}$, Cristiano Feldens Schwertner $^{3} \&$ Jocelia Grazia $^{1}$
}

1. Laboratório de Entomologia Sistemática, Departamento de Zoologia, Programa de Pós-Graduação em Biologia Animal, Universidade Federal do Rio Grande do Sul, Av. Bento Gonçalves, 9500, Bloco IV, prédio 43435, 91501-970 Porto Alegre, RS, Brazil. (ferrariaugusto@gmail.com; jocelia@ufrgs.br)

2. Departamento de Zoologia, Programa de Pós-Graduação em Entomologia, Universidade Federal do Paraná, Caixa Postal 19020 , 81531-980 Curitiba, PR, Brazil. (andri_bio@yahoo.com.br)

3. Departamento de Ciências Biológicas, Universidade Federal de São Paulo, Campus Diadema, Rua Prof. Artur Riedel, 275, 09972-270, Diadema, SP, Brazil. (acrosternum@yahoo.com.br)

\begin{abstract}
The definition of areas of endemism is central to studies of historical biogeography, and their interrelationships are fundamental questions. Consistent hypotheses for the evolution of Pentatomidae in the Neotropical region depend on the accuracy of the units employed in the analyses, which in the case of studies of historical biogeography, may be areas of endemism. In this study, the distribution patterns of 222 species, belonging to 14 Pentatomidae (Hemiptera) genera, predominantly neotropical, were studied with the Analysis of Endemicity (NDM) to identify possible areas of endemism and to correlate them to previously delimited areas. The search by areas of endemism was carried out using grid-cell units of $2.5^{\circ}$ and $5^{\circ}$ latitude-longitude. The analysis based on groupings of grid-cells of $2.5^{\circ}$ of latitude-longitude allowed the identification of 51 areas of endemism, the consensus of these areas resulted in four clusters of grid-cells. The second analysis, with grid-cells units of $5^{\circ}$ latitude-longitude, resulted in 109 areas of endemism. The flexible consensus employed resulted in 17 areas of endemism. The analyses were sensitive to the identification of areas of endemism in different scales in the Atlantic Forest. The Amazonian region was identified as a single area in the area of consensus, and its southeastern portion shares elements with the Chacoan and Paraná subregions. The distribution data of the taxa studied, with different units of analysis, did not allow the identification of individual areas of endemism for the Cerrado and Caatinga. The areas of endemism identified here should be seen as primary biogeographic hypotheses.
\end{abstract}

KEYWORDS. Areas of endemism, NDM, Atlantic Rain Forest, Amazonian region, grid-cells.

RESUMO. Análise de endemismo de táxons neotropicais de Pentatomidae (Hemiptera: Heteroptera). A definição de áreas de endemismo é central aos estudos de Biogeografia Histórica e suas inter-relações são questões fundamentais. Hipóteses consistentes sobre a evolução de Pentatomidae (Hemiptera) na Região Neotropical dependem da acuidade das unidades empregadas nas análises, que no caso de estudos de biogeografia histórica, podem ser áreas endêmicas. Neste trabalho foram estudados os padrões de distribuição de 222 espécies, pertencentes a 14 gêneros de Pentatomidae, com ocorrência predominantemente neotropical, com base em uma Análise de Endemicidade (NDM) a fim de inferir possíveis áreas endêmicas e relacioná-las a áreas previamente delimitadas. A busca por áreas endêmicas foi realizada com quadrículas de $2,5^{\circ}$ e $5^{\circ}$ latitude-longitude. A análise com base em agrupamentos de $2,5^{\circ}$ latitude-longitude permitiu identificar 51 áreas de endemismo, sendo que o consenso destas áreas resultou em quatro agrupamentos de quadrículas. A segunda análise, com quadrículas de $5^{\circ}$ latitude-longitude, resultou em 109 áreas de endemismo. O consenso flexível empregado resultou em 17 áreas de endemismo. As análises foram sensíveis à identificação de áreas de endemismo na Mata Atlântica em diferentes escalas. A região Amazônica foi identificada como uma área única no consenso, sendo que a porção sudeste compartilha elementos com as sub-regiões do Chaco e Paraná. Os dados de distribuição dos táxons estudados, com diferentes unidades de análises, não permitiram a identificação de áreas endêmicas para o Cerrado e a Caatinga. As áreas de endemismo aqui identificadas devem ser tratadas como hipóteses biogeográficas primárias.

PALAVRAS-CHAVE. Áreas endêmicas, NDM, Mata Atlântica, região amazônica, quadrículas.

The definition of areas of endemism is central to studies of historical biogeography, and the relationships among them are fundamental questions (NELSON \& Platnick, 1981; Henderson, 1991). In a way analogous to phylogenetic systematics, in which species or supraspecific taxa are grouped, units in biogeography are grouped as areas of endemism (LINDER, 2001). An area of endemism can be diagnosed through evaluation of the overlapping of the distribution areas of two or more species (Platnick, 1991; Morrone, 1994). However, as this overlapping is never total, somehow the identification of areas of endemism might be a subjective procedure. Assuming that these areas are the basic units of the historical biogeographic analysis, their definition, conceptual as well as methodological, play an essential role in biogeographic analyses (Platnick, 1991; Linder,
2001). According to CAVIERES et al. (2002), the use of areas of endemism in the identification of areas for conservation makes possible to identify priority areas not based only on the generally used criteria, such as species diversity and richness.

According to Morrone (2009), areas of endemism (or biotic elements) share a common history but may not represent monophyletic entities, due to events of reticulation caused by geographic dispersion or biogeographic convergence. The conformation of the areas can be the result of historical factors, associated with vicariance events, or a combination of ecologic factors that limit the area of occurrence of the taxa (NELSON \& Platnick, 1981; Hovenkamp, 1997; LafFan \& CRisp, 2003). The processes associated with dispersal presuppose that the organisms have a particular history 
through a stable geography. In this context, the spatial conformation of the distribution is due to the similar response of organisms to geographic barriers, where these organisms are confined to these areas. The vicariance process assumes that areas of endemism are formed from ancestral distribution areas, which fragment with the appearance of barriers, thereby dividing the biota into subpopulations, with different dispersal and colonizing capacities (EsPINOSA et al., 2001).

The methods in vicariance or cladistic biogeography assume that the limits of the distribution of species originating in the same area of endemism should be in general more congruent among themselves than with those of species originating in other areas of endemism (HAusdorf, 2002). In this context, the vicariance model presupposes that the limits of species distribution are not random (MORRONE, 1994; HAUSDORF, 2002). Based on these premises, we can hypothesize that the distribution of species showing some level of congruence can be the result of a close relation between the history of the earth and the history of the biotas (CROIZAT, 1964), which can allow to infer a particular pattern.

Morrone (2001) proposed two steps in the identification of areas of endemism: primary biogeographic homology, which refers to a conjecture on a common biogeographic history, inferred from different taxa integrated in spatial-temporal manner in a biota; and the secondary biogeographic homology, with regard to the use of cladistic results to test the primary homologies. Cladistic biogeography allows us to compare different area cladograms, by the substitution of the taxa by the areas of endemism in which they occur, making it possible to construct general hypotheses of the relation of the areas or general area cladograms (NELSON \& Platnick, 1981; Humphries \& Parenti, 1999). Different delimitations of areas of endemism can result in contradictory hypotheses of area relationships, as result of the substitution of the terminals by areas of occurrence, for the same collection of data analyzed (HENDERSON, 1991; HAUSDORF, 2002).

Szumik et al. (2002) and Szumik \& Goloboff (2004) proposed a method for identifying areas of endemism, which takes into consideration the spatial position of the localities of the taxa, and makes it possible to group gridcells (areas of endemism) based on indices (scores) of the endemic species of these grid-cells. The score of endemism of an area of endemism (cluster of grid-cells) is the result of the sum of the scores of endemism of the species that occur in these grid-cells.

In a comparative study with different methodologies for searching areas of endemism, involving 609 species of plants with occurrence in the archipelago of Canary Islands, CARINE et al. (2009) evaluated the performance of hierarchical methods such as parsimony analysis of endemicity (PAE) and UPGMA, relative to analysis of endemicity (NDM: eNDeMism) proposed by SzUMIK et al. (2002) and SzUMIK \& GolobofF (2004). According to these authors, the search algorithm NDM was superior to the hierarchical methods in number of areas found that satisfied the criteria used, and in the total areas found. Then, it is preferable to incorporate spatial information in the delimitation of the areas and accept overlapped areas of endemism.

The use of grid-cells in biogeographic studies is a frequent procedure, where their size is defined according to the area of study and the density of the distribution data of the taxa studied. The definition of the grid-cells can vary considerably, from restricted areas with a unit of $0.5^{\circ}$ (CAVIERES et al., 2002; Rovito et al., 2004) to $1^{\circ}$ (Sigrist \& CARVAlHo, 2008) to $2.5^{\circ}$ (Linder, 2001) and to $5^{\circ}$ for continental areas (CostA \& LeITE, 2000; GoldANi $e t$ al., 2002; Biondi \& D’AlessANDRo, 2006). Larger gridcells can include a higher number of single species and result in areas with greater support. However, using larger grid-cells increases the probability of including areas with greater heterogeneity of ecosystems, which can obscure possible biological patterns in grouping areas with little support (Morrone \& Escalante, 2002; Sigrist \& CARvalho, 2008).

Insects are especially important in studies that attempt to answer biogeographic questions and to understand global patterns of distribution, either by the age of the taxa or the diversity of species. The lack of knowledge of the distribution and phylogeny of the insects, and their high diversity has hampered the use of this group of organisms in biogeographic studies (Morrone, 2006). Works on the identification of areas of endemism with data for Hemiptera include studies with PAE in Cercopidae and Membracidae (Goldani et al., 2002; Goldani \& CARVAlHo, 2003) and in Heteroptera with Peiratinae (Reduviidae) (Morrone \& CoscArón, 1996), besides a panbiogeographic analysis of the genus Pselliopus Bergroth (Reduvidae: Harpactorinae) (MARINO-Perez et al., 2007). Morrone et al. (2004) used a panbiogeographic analysis to study the distribution patterns of 60 species of Belostomatidae, Corixidae, Micronectidae and Gerridae for the Chaco region. SigRIST $\&$ Carvalho (2008) conducted a PAE with 19 unrelated taxa, and included data of Serdia Stål, 1867 (Heteroptera, Pentatomidae). Thomas (2000) reviewed the literature and summarized the knowledge of the pentatomids occurring in Mexico. Based on the limits of distribution of these taxa, a classification of the biotic elements was proposed: Nearctic, Holarctic, Pan-Tropical and Neotropical, including in this last element a classification for endemic species of Mexico, where it recognizes nine biotic provinces selected among the 18 established by GOLDMAN \& MOORE (1945) based on vertebrates.

In this paper the distribution patterns of 14 predominantly Neotropical Pentatomidae (Hemiptera) genera were studied with the application of the Analysis of Endemicity (NDM) proposed by SzUMIK et al. (2002) and SzumiK \& Goloboff (2004), to recognize areas of endemism and to relate them to previously delimited areas.

\section{MATERIAL AND METHODS}

The groups included in the analysis were selected based on the following criteria: predominantly Neotropical distribution, recent taxonomic revision, with hypothesis of monophyly, and studies with detailed distribution information. Species with uncertain taxonomic position, subspecies, and species or specimens with incomplete 
or incongruent distribution data were not included in the analysis.

The latitude and longitude of the respective localities were defined according to the following databases: Global Gazetteer version 2.1 (FALLING RAIN Genomics, 2007), Species Link - GeoLoc (CRIA, 2007) and GLOSK (2008).

The analysis included 222 species (Appendix I), belonging to 14 genera of Pentatomidae, with a total of 1932 georeferenced points. Of the total species included, 50 had only one distribution point sampled. Among the species with only one locality surveyed, some are only known by the holotype, incomplete data or incongruent labeling. These species with single localities, despite not directly influencing the grouping of grid-cells, were included in the analysis, because they are covered in the fourth criterion proposed by SzUMIK et al. (2002) and can affect the indices of the areas.

The genera included in the analysis were the following (classification of the subfamilies and tribes according to Rider, 2009): Adevoplitus Grazia \& Becker, 1995 (5 spp.; Pentatominae: Pentatomini); Agroecus Dallas, 1851 (6 spp.; Pentatominae, Carpocorini), Antiteuchus Dallas, 1851 (38 spp.; Discocephalinae, Discocephalini), Arocera Spinola, 1837 (9 spp.; Pentatominae, Catacanthini), Brachystethus Laporte, 1833 (9 spp.; Edessinae), Cataulax Spinola, 1837 (5 spp.; Discocephalinae, Discocephalini), Chinavia Orian, 1965 (67 spp.; Pentatominae, Nezarini), Dichelops Spinola, 1837 (13 spp.; Pentatominae, Carpocorini), Evoplitus Amyot \& Serville, 1843 (1 sp.; Pentatominae, Pentatomini), Pallantia Stål, 1862 (4 spp.; Pentatominae, Pentatomini), Pseudevoplitus Ruckes, 1958 (3 spp.; Pentatominae, Pentatomini), Rio Kirkaldy, 1909 (17 spp.; Pentatominae, Menidini), Serdia Stål, 1860 (18 spp.; Pentatominae, Pentatomini), and Thyanta Stål, 1862 (27 spp.; Pentatominae, "unplaced") (list of species: see Appendix I).

Chinavia is composed of 84 species, where 13 are Afrotropical, two Nearctic, and 69 registered for South America. They are polyphagous and are reported to be associated with more than 30 families of plants (SCHWERTNER \& GRAZIA, 2006). Some species are pests of important crops, such as Chinavia acuta (Dallas, 1851) in Africa, C. hilaris (Say, 1831) in the United States and Canada and C. impicticornis (Stål, 1872) in Brazil (McPherson \& McPherson, 2000; Panizzi et al., 2000). The monophyly of the genus was established by SCHWERTNER (2005). The distribution data for Chinavia species and the respective localities were retrieved from Rolston (1983), RIDER (1986), RIDER \& Rolston (1987a), Schwertner (2005), Schwertner \& Grazia (2006) and GraZia et al. (2006).

BARCELlOS \& GRAZIA (2003a), in a cladistic analysis of 10 species of Brachystethus and genera included in Edessinae, demonstrated its monophyly and transferred the genus to this subfamily. Also, a biogeographic hypothesis for the genus was proposed, and associated some of the resulted dichotomies with vicariance events of the Cretaceous for the Neotropical region. The distribution data for the nine species included in Brachystethus were retrieved from BARCELLOS \& GRAZIA (2003b).
The distribution data for Serdia, a monophyletic genus that currently comprises 18 species, were retrieved from FORTES \& GRAZIA (2005), who revised the genus and inferred its monophyly based on a cladistic analysis.

GrAZIA (1997), in a cladistic analysis of the group Evoplitus - which includes Evoplitus, Pseudoevoplitus and Adevoplitus - corroborated the monophyly of the group and of the genera included. The localities of the nine species included were retrieved from GRAZIA et al. (1993; 1994), GRAZIA \& BECKER (1995) and GRAZIA et al. (2002).

Dichelops was reviewed by GRAZIA (1978) and its monophyly supported, including 14 species; the data referring to the localities were retrieved from the material examined (GRAZIA, 1978).

The South American species of the genus Thyanta were studied by RIDER \& CHAPIN (1991). In a subsequent study, Rider \& CHAPIN (1992) reviewed 14 species from North America, Central America and Antilles. The 27 Neotropical species were included in the analysis and the distribution data were retrieved from both.

The other species and respective localities analyzed were obtained from the following taxonomic revisions: Pallantia (Grazia, 1980), Agroecus (RIDER \& Rolston, 1987b), Arocera (RIDER, 1992), Rio (GRAZIA \& Fortes, 1995; Fortes \& Grazia, 2000), Cataulax (GraZia et al., 2000), and Antiteuchus (FERNANDES \& GRAZIA, 2006).

The search by areas of endemism was carried out using grid-cell units of $2.5^{\circ}$ and $5^{\circ}$ latitude-longitude. The two groups of grid-cells generated for Latin America and Caribbean islands were initiated at $-124.306^{\circ}$ longitude and $-41.474^{\circ}$ latitude. The areas analyzed include the Mexican Transition Zone, Neotropical region, South American Transition Zone and Andean region. The areas were compared with the classification proposed by Morrone (2006) (Fig.1).

Analysis of endemism (NDM/VNDM). The score of endemism of the species is defined based on four criteria (Szumik et al., 2002; Szumiк \& Goloboff, 2004). The first is the most restrictive, requiring total spatial congruence of the distribution of the species in the cluster of grid-cells in question, and when satisfied it is the one that most contributes to the score of the area. The second criterion does not require that all the species have identical distributions to contribute to the score of the area, where they can occur in grid-cells adjacent to the area in question. The third does not require that all the grid-cells of the area in question have the same composition of species, but only the species that occur in all the grid-cells contribute to the index. The fourth criterion takes into consideration, for the calculation of the score, the species absent in one or some of the gridcells of the area in question.

The algorithm used for calculation of the scores of endemicity include the following steps (SzUMIK et al., 2002; Szumik \& GolobofF, 2004): 1. Plot the localities of the species on a map with grid-cells. 2. Calculate the endemicity values for all possible groupings of grid-cells, considering the scores of the endemic species of these areas (clusters) in accordance with the four criteria defined by SzUMiK et al. (2002). 3. Choose the groupings of gridcells with score of endemism greater than 2. 4. Visualize 


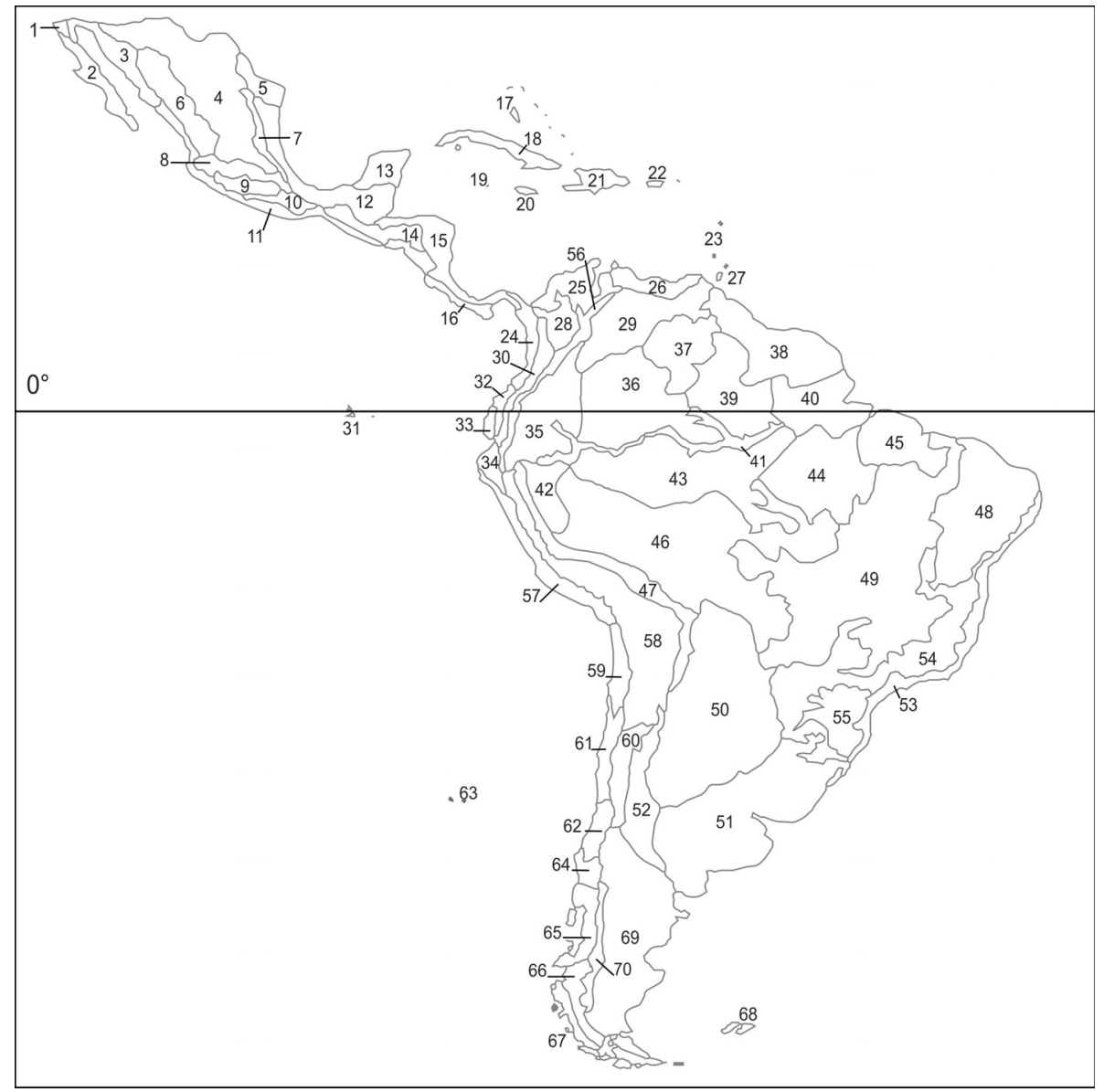

Figure 1. Biogeographic classification of Latin America and the Caribbean islands: 1, California; 2, Baja California; 3, Sonora; 4, Mexican Plateau; 5, Tamaulipas; 6, Sierra Madre Occidental; 7, Sierra Madre Oriental; 8, Transmexican Volcanic Belt; 9, Balsas Basin; 10, Sierra Madre del Sur; 11, Mexican Pacific coast; 12, Mexican Gulf; 13, Yucatan Peninsula; 14, Chiapas; 15, eastern Central America; 16, western Panamanian Isthmus; 17, Bahamas; 18, Cuba; 19, Cayman Islands; 20, Jamaica; 21, Hispaniola; 22, Puerto Rico; 23, Lesser Antilles; 24, Choco; 25, Maracaibo; 26, Venezuelan coast; 27, Trinidad and Tobago; 28, Magdalena; 29, Venezuelan Llanos; 30, Cauca; 31, Galapagos Islands; 32, western Ecuador; 33, arid Ecuador; 34, Tumbes-Piura; 35, Napo; 36, Imeri; 37, Guyana; 38, Humid Guyana; 39, Roraima; 40, Amapá; 41, Várzea; 42, Ucayali; 43, Madeira; 44, Tapajós-Xingu; 45, Pará; 46, Pantanal; 47, Yungas; 48, Caatinga; 49, Cerrado; 50, Chaco; 51, Pampa; 52, Monte; 53, Brazilian Atlantic forest; 54, Paraná Forest; 55; Araucaria angustifolia Forest; 56, North Andean Paramo; 57, coastal Peruvian Desert; 58, Puna; 59, Atacama; 60, Prepuna; 61, Coquimbo; 62, Santiago; 63, Juan Fernandez Islands; 64, Maule; 65, Valdivian forest; 66, Magellanic forest; 67, Magellanic Paramo; 68, Malvinas Islands; 69, Central Patagonia; 70, Subandean Patagonia (MORrone, 2006)

the groupings of grid-cells (areas of endemism) on a map. 5. Apply a criterion of consensus, when necessary, for the purpose of synthesize the information contained in clusters of similar grid-cells (with respect to composition of endemic species and grid-cells included) in an area of consensus.

In the present study, the areas of endemism were identified according to the concept of PLATNICK (1991), who assumed that the more or less congruent limits of distribution of two or more species represent areas of endemism. Obviously, in this context, congruence does not imply an exact overlapping of the limits for all the possible scales of cartographic representation, but rather a relative sympatry at the level of resolution desired for analysis (PLATNICK, 1991).

The method to search the areas of endemism was carried out with the program NDM v. 2.6 (GoLOBOFF, 2008) and visualized with VNDM (GoLOBOFF, 2008).

The options of heuristic searches were carried out keeping areas with at least two endemic species and score of endemism over 2. The option of permutation of one grid-cell each time was used. The randomization parameter of the searches was defined as zero ("random seed" $=0$ ). We did not use the filling option, which uses a ray from the points recorded on the map for defining the presence of species in the grid-cells. The absence of species was not inferred for grid-cells which did not have occurrence data. The calculation of the scores of the areas of endemism took into consideration the proportion of grid-cells that limited them.

The parameters of heuristic search used in the analysis were modified in comparative tests to estimate their effect on the results obtained. The results were little affected by the search parameters, where the consensus of the resultant areas remained unchanged.

The areas of endemism found by the search criterion of the NDM resulted in some cases in overlapping areas that differed with respect to the presence of a/some grid-cell(s) or endemic species(s). The areas of consensus summarize the information contained in these individual areas that share a certain 
percentage of endemic species, facilitating the comparison and discussion of the results, mainly when the number of resultant areas is very high. The flexible consensus was applied, with $40 \%$ minimal similarity of endemic species for the grouping of areas initially found, in the analyses with units of grid-cells of $2.5^{\circ}$ and $5^{\circ}$ latitudelongitude. The results of the flexible consensus also included individual areas (single) found by the initial analysis, when these did not satisfy the criteria employed in the consensus.

\section{RESULTS}

The analysis based on groupings of grid-cells of $2.5^{\circ}$ of latitude-longitude allowed the identification of 51 areas of endemism, with scores of endemism varying from 2.00 to 8.057 . The consensus of these areas resulted in four clusters of grid-cells (Figs 2-5).

Area 1 (Fig. 2) formed by two disjunct grid-cells situated in northern Colombia and northeastern Venezuela, included in the Caribbean sub-region, and within the Northwestern South American domain. Similar
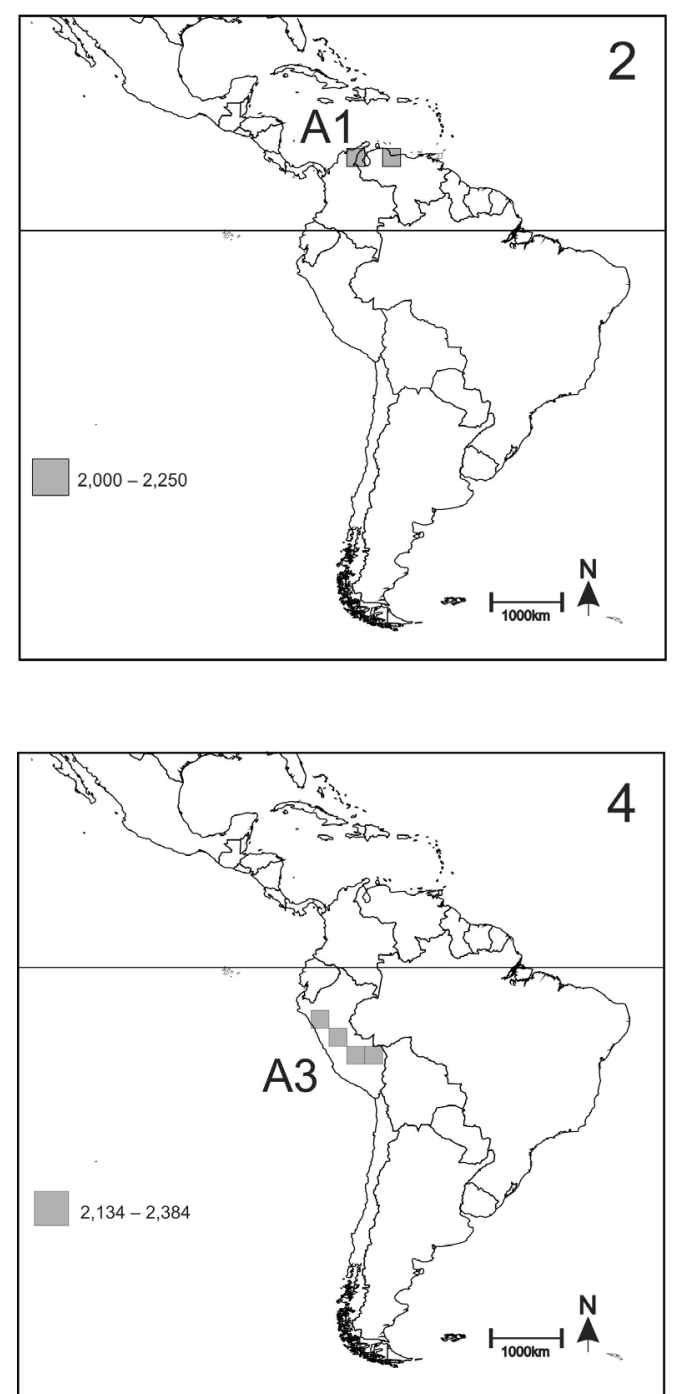

results were found in both analysis (grid-cells of $2.5^{\circ}$ and $5^{\circ}$ ), showing the same species for areas 1 and 8 (Tab. I). Area 1 contains Thyanta obtusa Rider, 1991 and T. sinuata Rider, 1991, both with endemicity score of 1, as a result of spacial congruence in the two grid-cells.

Forty six areas are related to the grid-cells situated in the Atlantic Forest biogeographic province, and included in the consensus of area 2 (Fig. 3), with 28 endemic species (Tab. I). The grid-cells with greater score of endemism, varying from 7.220 to 8.057, are composed by species that occur predominantly in the Brazilian Atlantic Forest and Araucaria angustifolia Forest. With exception of Chinavia longicorialis (Breddin, 1901) Pampa, C. obstinata (Stål, 1860) - Pampa, Serdia inspersipes Stål, 1860 - Pampa, and Dichelops avilapiresi Grazia, 1978 - Chaco, this area of consensus corresponds to the portion with the greatest score of endemism of area 13 (Fig. 14), in the analysis with grid-cells of $5^{\circ}$, in the Atlantic Forest domain.

Two areas of endemism (not represented graphically) were found with scores varying from 2.43 to 2.73 , occurring in different portions of the Atlantic Forest
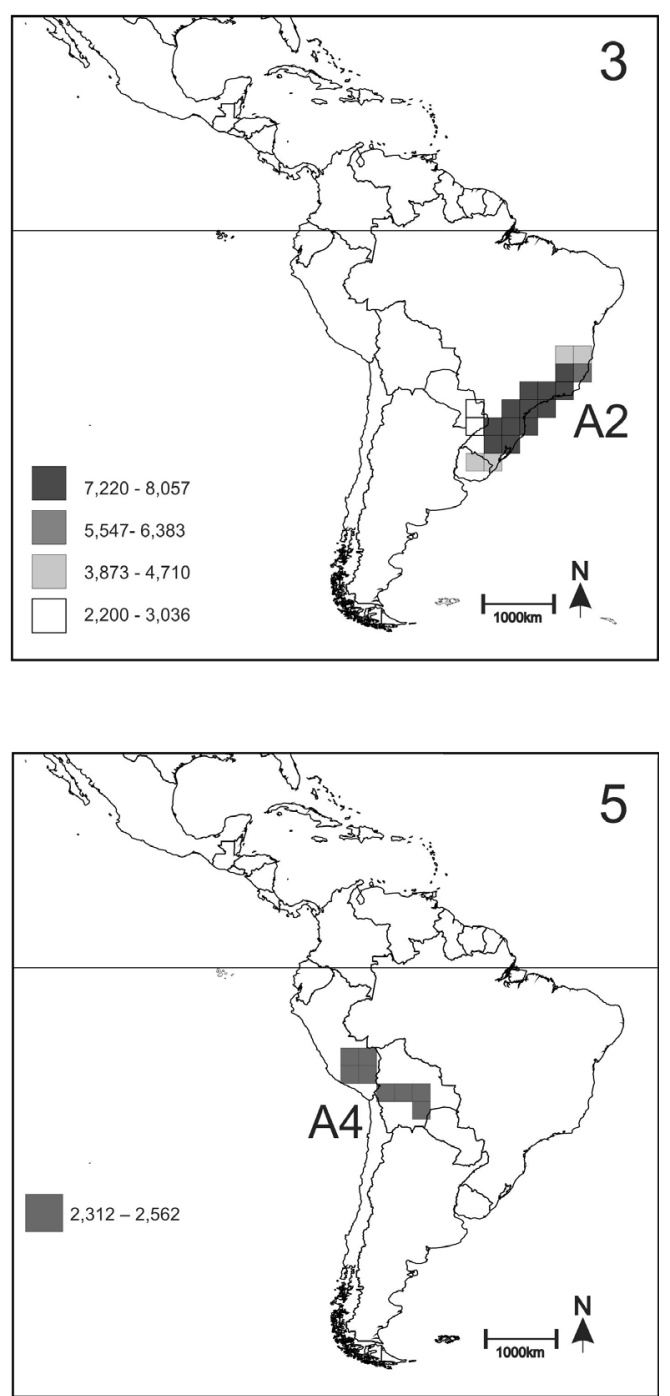

Figures 2-5. Consensus of the areas of endemism resulting from the analysis based on grid-cells of $2.5^{\circ}$ latitude-longitude: 2 , area $1 ; 3$, area $2 ; 4$, area 3; 5 , area 4 (for endemic taxa of the areas and respective scores of endemism, see table I). 
and not included in the consensus of area 2 (Fig. 3) by the criterion used. One of these areas is formed by a grouping of five grid-cells, situated between Espírito Santo and northern Paraná. The second area is composed of the grouping of 10 grid-cells, extending from northeastern Uruguay up to southern Paraná.

Area 3 (Fig. 4) is formed by four grid-cells, situated on a diagonal in the southeast/northeast direction in Peru, sharing two of the three endemic species found in area 10 (Fig. 11) with grid-cells of $5^{\circ}$.

Area 4 (Fig. 5) is composed of three endemic species, covering eight grid-cells situated in southern Peru and southeastern Bolivia, and sharing the presence of Thyanta boliviensis Rider, 1991 with area 9 (grid-cells with $5^{\circ}$ - Fig. 10). Areas of endemism 3 and 4 are located predominantly in the Yungas province (Tab. I), which belongs to the Amazonian Subregion. Area 3 also includes portions at the extreme north of the Puna province, and area 4 extends to the southeast, forming clusters that overlap in 2 grid-cells, but showing a distinct composition of species (Tab. I).

The second analysis searched for groups of gridcells with two or more endemic species, with analysis units of $5^{\circ}$ latitude-longitude, and resulted in 109 areas of endemism. The highest index of endemicity of the initial cluster was 20.08, for an area with four grid-cells found in the Atlantic Forest and included in the consensus of area 13 (Fig. 14). The flexible consensus employed resulted in 17 areas of endemism (Figs. 6-22).

Consensus area 5 (Fig. 6) results from six initial clusters encompassing 12 endemic species (Tab. I). The area is situated predominantly in the Mesoamerican domain, including all its provinces. The consensus area even includes the provinces of the Mexican transition zone, with Arocera melanopyga Stål, 1858 and Chinavia solita Rider \& Rolston, 1986 in the Sierra Madre Oriental, with A. melanopyga Stål, 1858 and Brachystethus rubromaculatus Dallas, 1851 in the Sierra Madre del Sur provinces; and in the Nearctic region, Antiteuchus innocens Engleman, 1976 with distribution in the south of the Mexican Plateau province.

Areas 6 (Fig. 7), 7 (Fig. 8) and 8 (Fig. 9) show occurrence between the limits south of the Mesoamerican domain and northeast of the Antillean domain; area 6 is composed of four endemic species, area 7 of three and area 8 of six (Tab. I).

Area 9 (Fig. 10), with four endemic species, occur in the South American transition zone provinces (Coastal Peruvian Desert, Puna and Atacama) and Thyanta boliviensis Rider, 1991 to the south of Yungas (Amazonian subregion). Area 10 (Fig. 11) with six endemic species two of Thyanta and two of Serdia (Tab. I) - encompasses the provinces of Tumbes-Piura, Napo, Yungas and North Andean Paramo.

Area 11 (Fig. 12) consists of 12 grid-cells and 12 endemic species, two shared with area 9 and two with area 10, with Thyanta xerotica Rider, 1991 being common to the three areas (Tab. I). The area results from the consensus of six groupings of the initial search, with limits on the north and south corresponding to those of areas 9 and 10. Area 11 includes areas 3 and 4, resulting from the search with grid-cells of $2.5^{\circ}$, showing variation in the scores of endemism for the species included in the groupings (Tab. I).

Area 12 (Fig. 13) is composed of eight grid-cells containing four endemic species (Tab. I) in the provinces of Yungas (to the south) and Chaco (to the extreme west) and in the South American transition zone (Monte, Prepuna and Puna) and Andean region (Coquimbo, Santiago and north of Central Patagonia).

Consensus area 13 (Fig. 14) is the result of 58 initial clusters of grid-cells and integrates 56 species (Tab. I). Consensus area 13 has a wide geographic range in the analyzed area and includes the greater part of the groupings initially found in the analysis of $5^{\circ}$ (58 of 109 groupings). This result can be a consequence of the type of consensus employed, of overlapping areas of endemism or even of taxa with wide distribution. The groupings initially found, which compose the consensus area 13, varied from 4 to 13 grid-cells, with scores of endemism between 2.21 and 20.08. The consensus area is composed predominantly by species of Chinavia (19 spp.), Serdia (9 spp.), Dichelops (8 spp.), Thyanta (5 spp.) and Agroecus (3 spp.). Altogether, these five genera encompass 44 species and a large part of the diversity of area 13. Consensus area 13 includes the following provinces: Pantanal province, to the south and southeast; the south of Yungas province; all the provinces of the Chacoan subregion, with the Caatinga at least to the extreme south and Cerrado to the southeast; the provinces of the Paraná subregion, with the species that most contributed to the scores of endemism of the consensus occurring in this area; in the South American transition zone, the extreme east of the Puna and Prepuna provinces, and in the Andean region, the Santiago and Central Patagonia provinces.

Area 14 (Fig. 15) is composed of eight endemic species, situated in the Parana subregion provinces, a portion to the south of Cerrado and to the extreme east of Pantanal provinces (Tab. I). Area 15 (Fig. 16) shows 11 endemic species, where three are shared with area 14 and seven with area 13

The Atlantic Forest biogeographic province was identified by other clusters of grid-cells, besides those included in consensus 13,14 and 15. Area of endemism 16 (Fig. 17) is composed of three widely distributed species, including several biogeographic provinces (Tab. I). Area 17 (Fig. 18) is constituted by three endemic species, two of these not occurring in area 13, including all the Paraná subregion and the limits on the east of Chaco, Pampa, Cerrado and Caatinga.

The second area in number of groupings included in the consensus was area 18 (Fig. 19), resulting from 18 groupings of the initial search and with 21 endemic species (Tab. I). Area 18 corresponds to the Amazon Forest biogeographic province, and the initial clusters of gridcells that resulted in this area, varied from 4 to 14 gridcells. There was a considerably distinct composition of species and geographic position, from well centralized areas (grid-cells with higher score of endemism of Fig. 19) to groupings restricted to the south, southwest or east of the consensus. Antiteuchus contributed most to the definition of the area, with 12 species, followed by Chinavia (4 spp.) and Rio (2 spp.). The area of endemism 
18 includes all provinces of the Amazonian subregion, with the exception of Guyana and Yungas, and includes even a portion of northeastern Cerrado, which belongs to the Chacoan subregion.
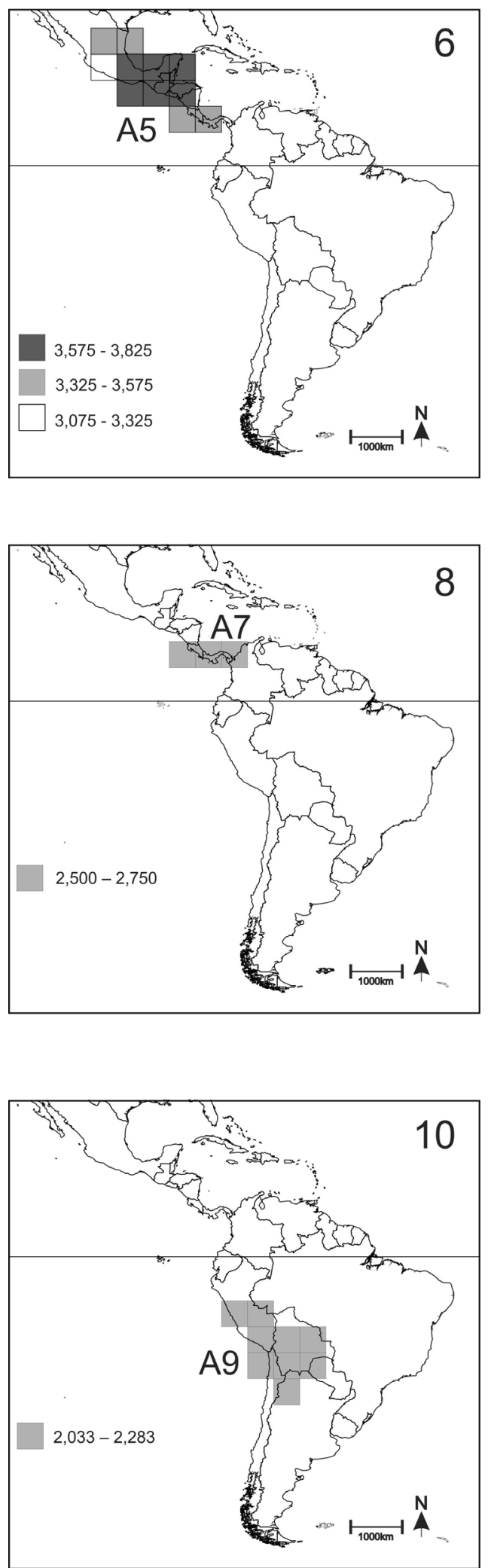

Figures 6-11. Consensus of the areas of endemism resulting from the analysis based on grid-cells of $5^{\circ}$ latitude-longitude: 6 , area $5 ; 7$, area $6 ; 8$, area $7 ; 9$, area $8 ; 10$, area $9 ; 11$, area 10 (for endemic taxa of the areas and respective indices of endemism, see table I).

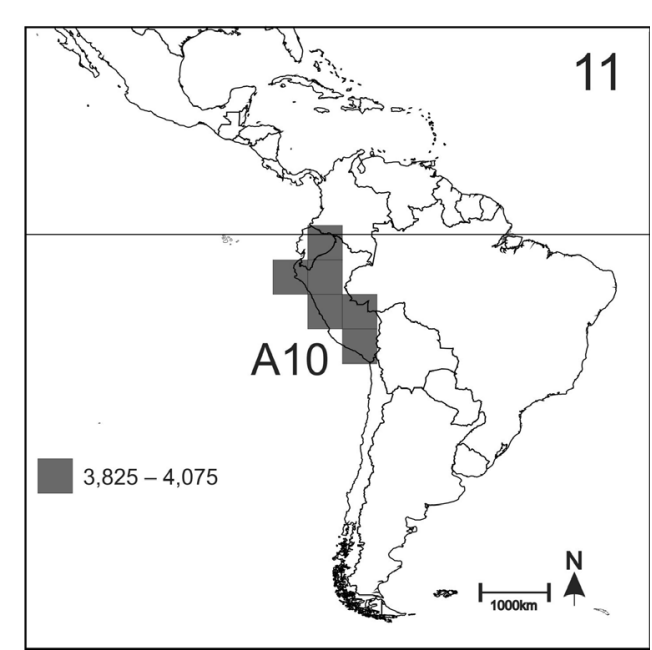

Area 19 (Fig. 20), with four endemic species, is formed by 10 grid-cells in two disjunct groupings, with the portion to the northeast composed of six grid-cells in the Amazon region, including Guyana, Várzea, Amapá,
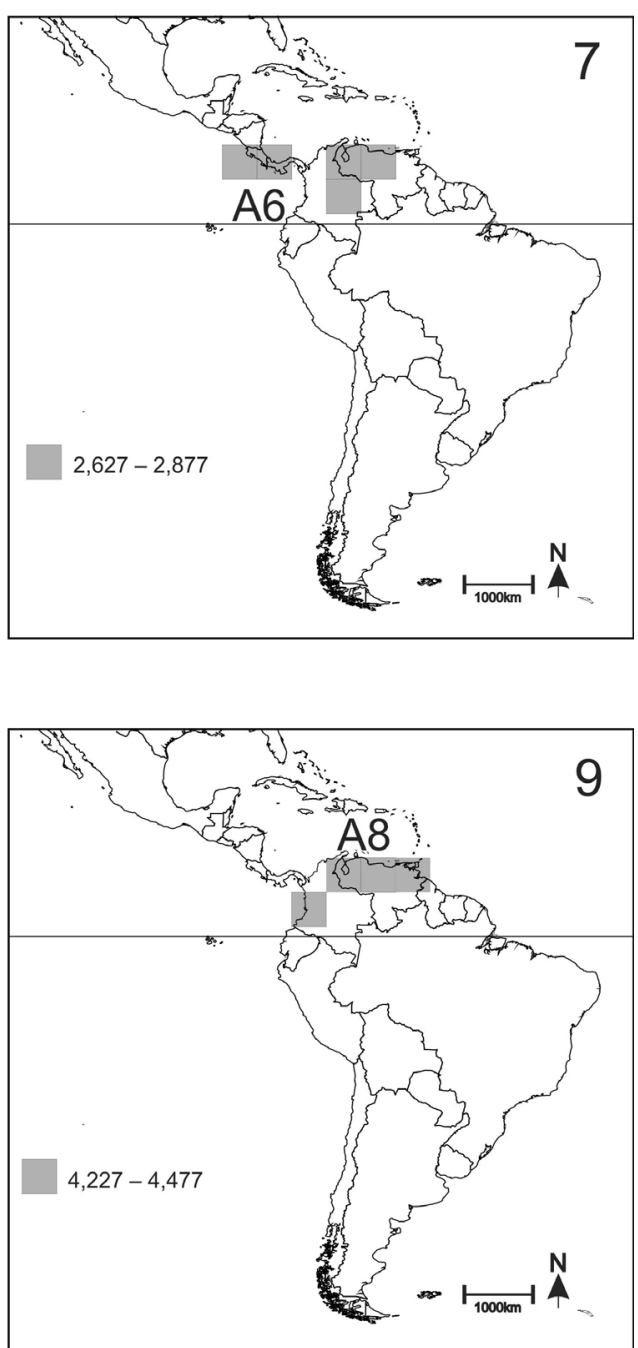
Table I. Areas of endemism identified in the analysis of $2.5^{\circ}$ (areas 1-4) and $5^{\circ}$ latitude - longitude (areas 5-21) and respective endemic species. The numbering of the biogeographic provinces corresponds to figure 1 . Areas partially overlapping the biogeographic provinces are indicated by the portion occupied in parentheses, with the following notation: N, north; S, south; E, east; W, west.

\begin{tabular}{|c|c|c|}
\hline Endemic area & $\begin{array}{l}\text { Biogeographic provinces } \\
\text { (MoRRONE, 2006) included } \\
\text { in the areas of endemism }\end{array}$ & $\begin{array}{l}\text { Endemic species included in the areas of endemism } \\
\quad \text { (indices of endemism between parentheses) }\end{array}$ \\
\hline A1 (Fig. 2) & 25,26 & Thyanta obtusa (1.000); Thyanta sinuata (1.000). \\
\hline A2 (Fig. 3) & $53,54,55$ & $\begin{array}{l}\text { Agroecus brevicornis }(0.000-0.714) ; \text { A. scabricornis }(0.000-0.682) ; \text { Antiteuchus nebulosus } \\
(0.000-0.667) ; \text { A. radians }(0.000-0.778) ; \text { A. tesselatus }(0.000-0.667) ; \text { Cataulax eximius } \\
(0.000-0.740) ; \text { Chinavia brasicola }(0.000-0.750) ; \text { C. difficilis }(0.000-0.682) ; \text { C. esmeralda } \\
(0.000-0.750) ; \text { C. longicorialis }(0.000-0.553) ; \text { C. obstinata }(0.000-0.639) ; \\
\text { C. pontagrossensis }(0.000-0.667) ; \text { C. geniculata }(0.000-0.643) ; \text { Dichelops avilapiresi } \\
(0.000-0.735) ; \text { D. punctatus }(0.000-0.857) ; \text { Evoplitus humeralis }(0.000-0.746) ; \\
\text { Pallantia macula }(0.000-0.875) ; \text { Serdia apicicornis }(0.000-0.786) ; S . \text { bicolor } \\
(0.000-0.625) ; S . \text { calligera }(0.000-0.729) ; S . \text { concolor }(0.000-0.900) ; \text {. inspersipes } \\
(0.000-0.686) ; \text { S. lobata }(0.000-0.750) ; S . \text { maxima }(0.000-0.586) ; S . \text { robusta } \\
(0.000-0.786) ; \text { Thyanta fimbriata }(0.000-0.714) ; \text { T. robusta }(0.000-0.643) .\end{array}$ \\
\hline A3 (Fig. 4) & $47,58(\mathrm{~N})$ & Antiteuchus peruensis (0.635); Serdia quadridens (0.750); S. ruckesi (0.750). \\
\hline A4 (Fig. 5) & 47 & Agroecus ecuadoriensis (0.688); Brachystethus vexillum (0.750); Thyanta boliviensis (0.875). \\
\hline A5 (Fig. 6) & $\begin{array}{l}4(\mathrm{~S})-7-8-9- \\
10-11-12- \\
13-14-15-16\end{array}$ & $\begin{array}{l}\text { Adevoplitus mexicanus }(0.000-0.800) ; \text { Antiteuchus costaricensis }(0.000-0750) ; \\
\text { A. innocens }(0.000-0.929) ; \text { Arocera melanopyga }(0.000-0.232) ; \text { Brachystethus } \\
\text { rubromaculatus }(0.000-1.000) ; \text { Chinavia scutellata }(0.000-0.714) ; \text { C. solita } \\
(0.000-0.525) ; \text { C. triangula }(0.000-0.667) ; \text { Rio obscuratus }(0.000-0.667) ; \text { R. testaceus } \\
(0.000-1.000) ; \text { R. variegatus }(0.000-0.643) ; \text { Serdia beckerae }(0.000-0.750) .\end{array}$ \\
\hline A6 (Fig. 7) & $\begin{array}{l}15(\mathrm{~S})-16-25- \\
26-29(\mathrm{~N})-56\end{array}$ & $\begin{array}{c}\text { Brachystethus improvisus }(0.655) ; \text { Cataulax pudens }(0.700) \\
\text { Chinavia ista }(0.700) ; \text { Rio insularis }(0.573) .\end{array}$ \\
\hline A7 (Fig. 8) & $15(\mathrm{~S})-16$ & Antiteuchus costaricensis (0.833); Chinavia macdonaldi $(0.833)$; Serdia beckerae $(0.833)$. \\
\hline A8 (Fig. 9) & $\begin{array}{c}25-26- \\
29(\mathrm{~N})-56\end{array}$ & $\begin{array}{c}\text { Brachystethus signoretii }(0.614) ; \text { Rio insularis }(0.614) ; \text { Thyanta obtusa }(0.750) \\
\text { T. testacea }(0.750) ; T \text {. sinuata }(0.750) ; T . \text { vadosa }(0.750) .\end{array}$ \\
\hline A9 (Fig. 10) & $\begin{array}{l}47(\mathrm{~S})-57- \\
58-59\end{array}$ & $\begin{array}{c}\text { Chinavia chilensis }(0.625-0.700) ; \text { Thyanta boliviensis }(0.000-0.813) \\
\text { T. rubicunda }(0.596-0.677) ; \text { T. xerotica }(0.000-0.677)\end{array}$ \\
\hline A10 (Fig. 11) & $\begin{array}{c}34-35-47(\mathrm{~N})- \\
56(\mathrm{~S})-58(\mathrm{~N})\end{array}$ & $\begin{array}{l}\text { Antiteuchus pictus }(0.677) ; \text { Chinavia plaumanni }(0.667) ; \text { Serdia quadridens } \\
(0.667) ; \text { S. ruckesi }(0.667) ; \text { Thyanta hamulata }(0.545) ; \text { T. xerotica }(0.614) \text {. }\end{array}$ \\
\hline A11 (Fig. 12) & $\begin{array}{l}42-46-47- \\
57-58-59\end{array}$ & $\begin{array}{c}\text { Agroecus ecuadoriensis }(0.625-0.700) ; \text { Antiteuchus graziae }(0.000-0.536) ; \text { A. mimeticus } \\
(0.000-0.643) ; \text { A. peruensis }(0.000-0.700) ; \text { A. variegatus }(0.000-0.489) ; \text { Brachystethus } \\
\text { vexillum }(0.688-0.800) ; \text { Chinavia chilensis }(0.000-0.700) ; \text { C. occulta }(0.000-0.667) ; \\
\text { Serdia quadridens }(0.000-0.700) ; \text { S. ruckesi }(0.000-0.700) ; \text { Thyanta boliviensis } \\
(0.533-0.857) ; \text { T. xerotica }(0.000-0.485) \text {. }\end{array}$ \\
\hline A12 (Fig. 13) & $\begin{array}{c}47(\mathrm{~S})-50(\mathrm{~W})-52- \\
58-60-61-62-69(\mathrm{~N})\end{array}$ & $\begin{array}{c}\text { Chinavia apicicornis }(0.563) ; \text { Dichelops lobata }(0.625) \\
\text { Thyanta acutangula }(0.563) ; \text { T. rubicunda }(0.582) .\end{array}$ \\
\hline A13 (Fig. 14) & $\begin{array}{l}46-47(\mathrm{~S})-48(\mathrm{~S})- \\
49(\mathrm{~S})-50-51- \\
52-53-54- \\
55-58(\mathrm{E})-60- \\
62-69(\mathrm{~N})\end{array}$ & 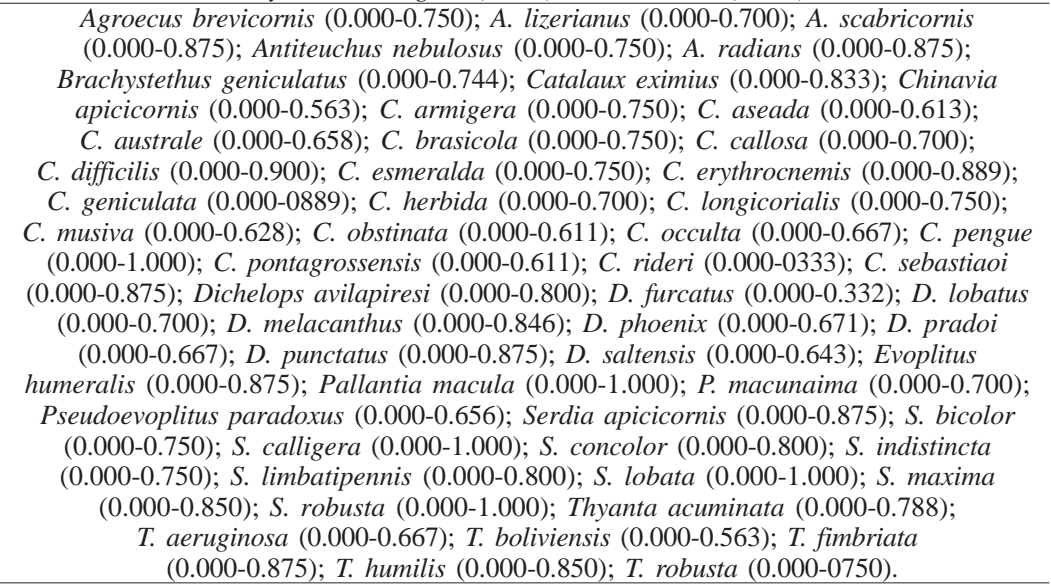 \\
\hline A14 (Fig. 15) & $\begin{array}{c}46-48(S)- \\
49-53-54-55\end{array}$ & $\begin{array}{c}\text { Arocera acroleuca }(0.288-0.625) ; \text { Chinavia obstinata }(0.404-0.580) ; \text { C. rideri }(0.635-0.643) ; \\
\text { Dichelops phoenix }(0.370-0.536) ; \text { D. pradoi }(0.000-0.688) ; \text { Pallantia macunaima } \\
(0.000-0.625) ; \text { Serdia inspersipes }(0.519-0.696) ; \text { S. maxima }(0.404-0.580) \text {. }\end{array}$ \\
\hline A15 (Fig. 16) & $\begin{array}{l}46(\mathrm{~S})-47(\mathrm{~S})-48(\mathrm{~S})- \\
49-50(\mathrm{~N})-51(\mathrm{NE})- \\
53-54-55\end{array}$ & $\begin{array}{l}\text { Arocera acroleuca }(0.000-0.833) ; \text { A. spectabilis }(0.000-0.677) ; \text { Brachystethus geniculatus } \\
\quad(0.000-0.719) ; \text { Cataulax eximius }(0.000-0.750) ; \text { Chinavia immaculata }(0.000-0.611) ; \\
\text { C. rideri }(0.000-0.778) ; \text { Dichelops pradoi }(0.000-0.667) ; \text { D. phoenix }(0.000-0.696) ; \\
\text { D. saltensis }(0.000-0.625) ; \text { Serdia indistincta }(0.000-0.592) ; \text { Thyanta acuta }(0.000-0.570) \text {. }\end{array}$ \\
\hline A16 (Fig. 17) & $\begin{array}{l}46(\mathrm{~S})-47(\mathrm{~S})-49(\mathrm{~S})-50- \\
51(\mathrm{~N})-53-54-55-58(\mathrm{E})\end{array}$ & $\begin{array}{c}\text { Dichelops furcatus }(0.472) ; \text { Thyanta acuminata }(0.575) ; \text { T. acuta }(0.684) ; \\
\text { T. braziliensis }(0.564) .\end{array}$ \\
\hline A17 (Fig. 18) & $\begin{array}{l}48-49(\mathrm{E})-50(\mathrm{E})- \\
51(\mathrm{NE})-53-54-55\end{array}$ & $\begin{array}{c}\text { Arocera spectabilis }(0.792) ; \text { Brachystethus geniculatus }(0.833) ; \\
\text { Chinavia nigridorsata }(0.729) .\end{array}$ \\
\hline A18 (Fig. 19) & $\begin{array}{l}35-36-39-40(\mathrm{~S})- \\
41-42(\mathrm{E})-43-44- \\
45(\mathrm{E})-46-49(\mathrm{NE})\end{array}$ & $\begin{array}{c}\text { Antiteuchus beckerae }(0.000-0.578) ; \text { A. doesburgi }(0.000-0.667) ; \text { A. exiguus } \\
(0.000-0.750) ; \text { A. geometricus }(0.000-0.750) ; \text { A. graziae }(0.000-0.657) ; \text { A. ledeburi } \\
(0.000-0.643) ; \text { A. pallescens }(0.000-0.731) ; \text { A. punctissimus }(0.000-0.714) ; \text { A. rideri } \\
(0.000-0.643) ; \text { A. schuhi }(0.000-0.722) ; \text { A. simulatus }(0.000-0.722) ; \text { A. variegatus } \\
(0.000-0.722) ; \text { Cataulax subtiliterconspersus }(0.000-0.786) ; \text { Chinavia gravis } \\
(0.000-0.567) ; \text { C. occulta }(0.000-0.700) ; \text { C. pecosa }(0.000-0.643) ; \text { C. vanduzeei }\end{array}$ \\
\hline
\end{tabular}


Tab. I (cont.)

\begin{tabular}{|c|c|c|}
\hline & & $\begin{array}{c}\text { (0.000-0.638); Dichelops leucostigmus }(0.000-0.622) ; \text { Pseudoevoplitus vitattus } \\
(0.000-0.700) ; \text { Rio clipeatus }(0.000-0.700) ; \text { R. punctatus }(0.000-0.667) .\end{array}$ \\
\hline A19 (Fig. 20) & $\begin{array}{c}37-41-44- \\
49-53-54(\mathrm{SE})\end{array}$ & $\begin{array}{l}\text { Antiteuchus rideri }(0.532) ; \text { Brachystethus vicinus }(0.700) \\
\text { Dichelops leucostigmus }(0.700) ; \text { D. nigrum }(0.510)\end{array}$ \\
\hline A20 (Fig. 21) & & $\begin{array}{c}\text { Antiteuchus mixtus }(0.602-0.726) ; \text { A. tripterus }(0.000-9.761) ; \text { Chinavia impicticornis } \\
(0.536-0.658) ; \text { C. runaspis }(0.629-0.684) ; \text { T. perditor }(0.000-0.684) \text {. }\end{array}$ \\
\hline A21 (Fig. 22) & & $\begin{array}{l}\text { Antiteuchus macraspis }(0.534) ; \text { A. tripterus }(0.645) \\
\text { Arocera apta }(0.595) ; \text { Thyanta perditor }(0.714) .\end{array}$ \\
\hline
\end{tabular}
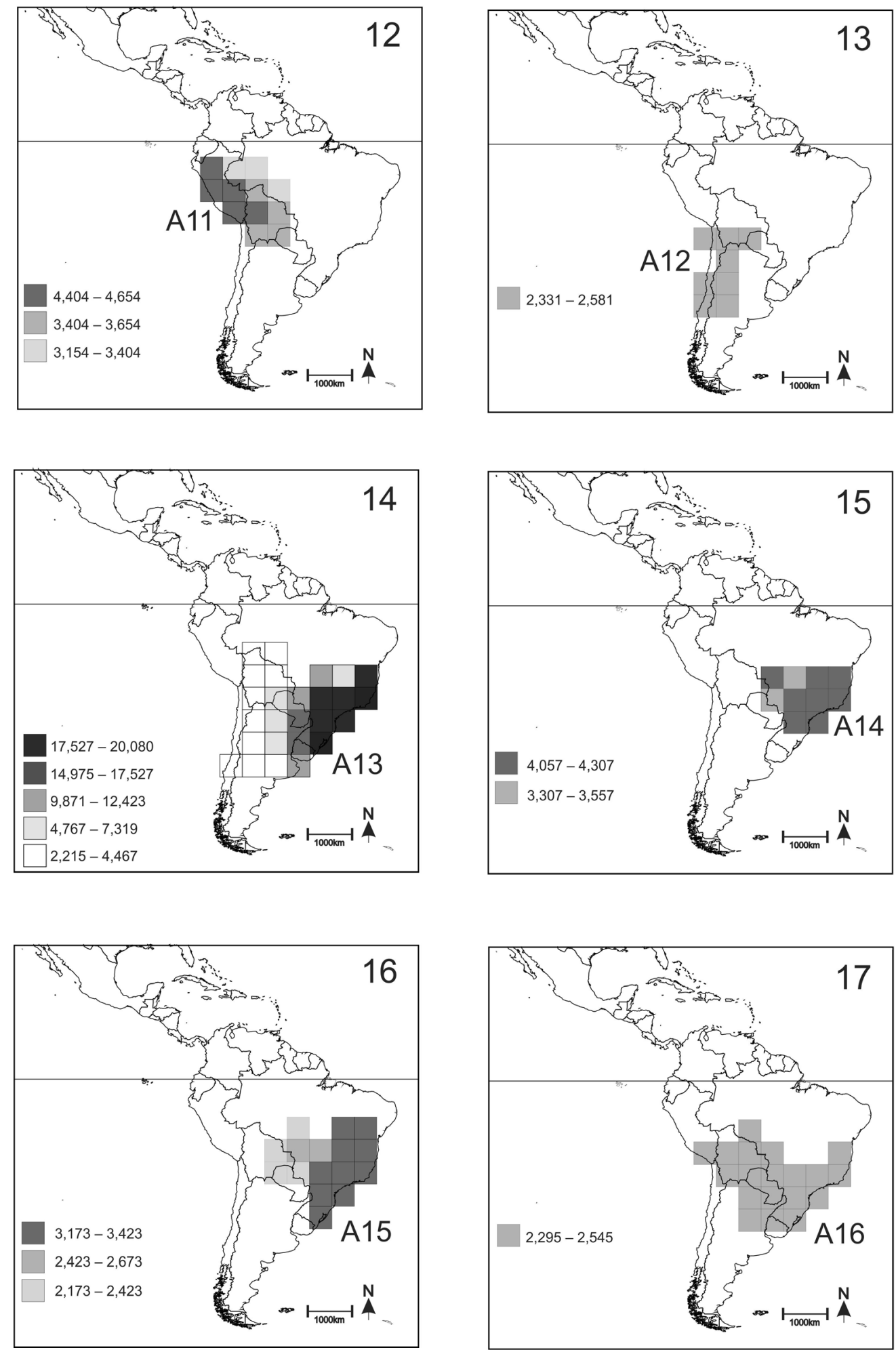

Figures 12-17. Consensus of the areas of endemism resulting from the analysis based on grid-cells of $5^{\circ}$ latitude-longitude: 12 , area $11 ; 13$, area $12 ; 14$, area $13 ; 15$, area $14 ; 16$, area $15 ; 17$, area 16 (for endemic taxa of the areas and respective scores of endemism, see table I). 
Tapajós-Xingu and east of the Pará province. The portion to the south of the area is constituted by four grid-cells in the central region and southeast of the Cerrado, Brazilian Atlantic Forest and Paraná Forest. All species included in area 19 occur in both disjunct portions, but Brachystetus vicinus Signoret, 1851 and Dichelops leucostigmus (Dallas, 1851) were the species that contributed most to the scores of the grouping (Tab. I).
Areas 20 (Fig. 21) and 21 (Fig. 22), with five and four endemic species respectively, result in wide areas between parallels $11^{\circ} \mathrm{N}$ and $28^{\circ} \mathrm{S}$ and $11^{\circ} \mathrm{N}$ and $33^{\circ} \mathrm{S}$. These areas include all the provinces of the Neotropical region and the portions to the east of Puna province, which belong to the South American transition zone. These areas differ in the following: area 21 includes the Western Panamanian Isthmus,
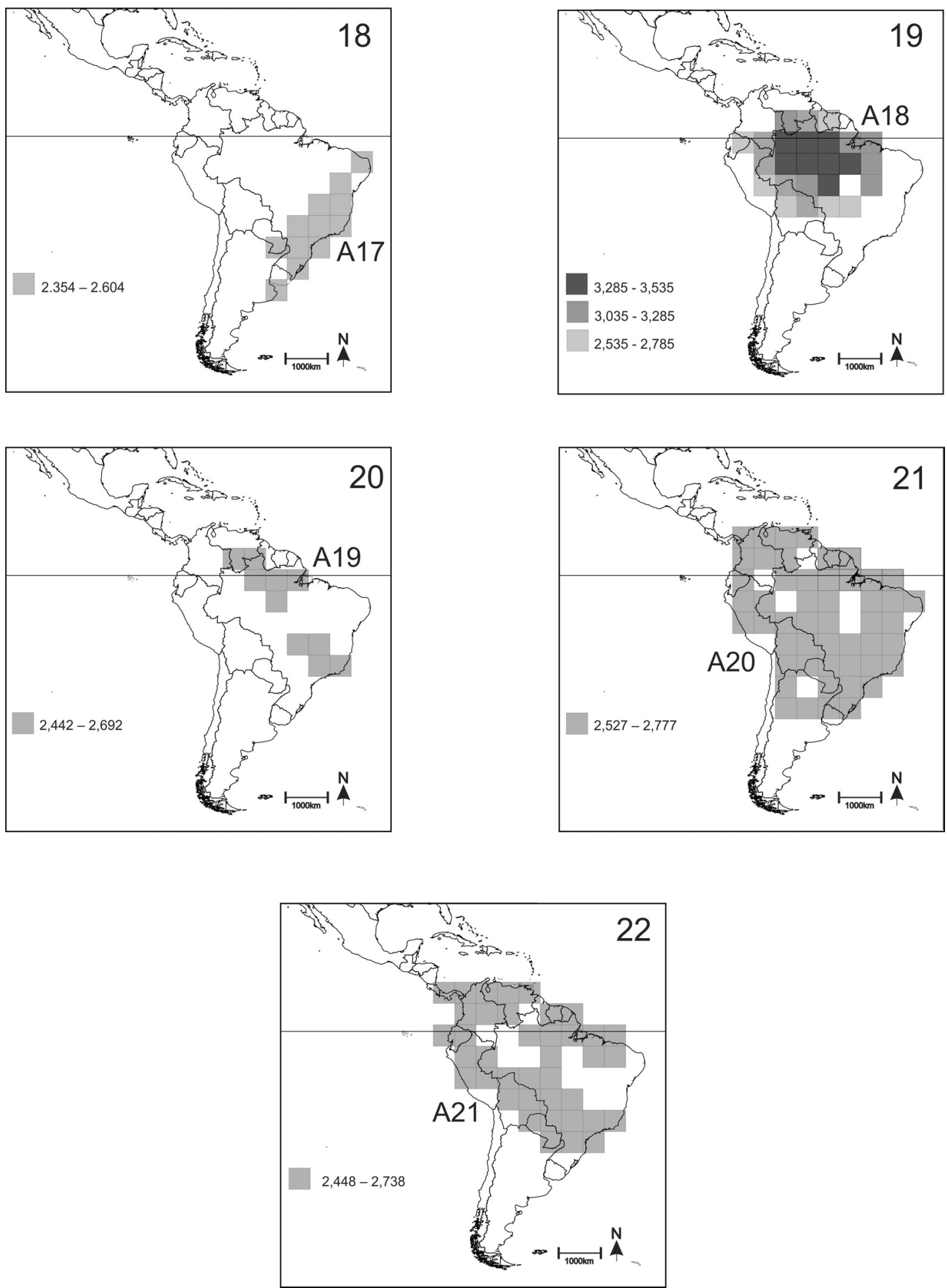

Figures 18-22. Consensus of the areas of endemism resulting from the analysis based on grid-cells of $5^{\circ}$ latitude-longitude: 18, area $17 ; 19$, area $18 ; 20$, area $19 ; 21$, area $20 ; 22$, area 21 (for endemic taxa of the areas and respective scores of endemism, see table I). 
while area 20 is southern, including portions of the Pampa and Chaco provinces.

The archipelago of Galapagos is included in a gridcell of $5^{\circ}$ latitude-longitude, with Chinavia viridans Stål, 1859, Thyanta setigera Ruckes, 1957 and T. similis Van Duzee, 1933 restricted to the area. C. viridans was recorded for Panama (RoLsTON, 1983) with no locality specified, maybe as an error. Both species of Thyanta was recorded only to Galapagos (RIDER \& CHAPIN, 1991).

No grouping of grid-cells (areas of endemism) was identified for the Caribbean islands, despite various species having a distribution restricted to this region: $C$. euri occurring in Mayaguana Island (archipelago of the Bahamas); C. insulani (Rolston, 1983) endemic to the Dominican Republic; C. sparnia (Dallas, 1851) endemic to Jamaica; C. wygodzinskyi (Rolston, 1983) occurring in the Grand Bahamas islands, Dominican Republic and British Virgin Islands ("Guana Island" and "Virgin Gorda Island"). Chinavia has three species occurring in the Caribbean islands and continental areas: C. collis (Rolston, 1983) in Cuba and in Costa Rica; C. marginata (Palisot de Beauvois, 1817), widely distributed in Central America, northeast of South America, Dominican Republic and Jamaica; and C. montivaga (Distant, 1890) with records for the Dominican Republic, Jamaica, Panama and Honduras.

\section{DISCUSSION}

Area 2 is composed predominantly by species of Chinavia (7 spp.), Serdia (7 spp.), Antiteuchus (3 spp.), Agroecus (2 spp.), Dichelops (2 spp.) and Thyanta (2 spp.). This area encompasses all of the Paraná subregion, which includes the provinces of the Brazilian Atlantic Forest, Paraná Forest and Araucaria angustifolia Forest, and two grid-cells in the Pampa with a lower score of endemism (Fig. 3). Area 2 is limited on the west by the Rio Paraná, where only Serdia concolor Ruckes, 1958 and Dichelops avilapiresi Grazia, 1978 cross this border. To the south of the area, only Chinavia longicorialis (Breddin, 1901) occurs outside of the grid-cells with a lower score. The limits of the species distribution included in area 2 are broadly congruent with the limits proposed by Morrone (2006). Based on the distribution of Peiratinae (Heteroptera: Reduviidae), Morrone \& Coscarón (1996) inferred an intimate relation between the Brazilian Atlantic Forest and Paraná Forest provinces, a pattern corroborated by the data obtained here. The Rio Doce limits the northern occurrence of the species of this grouping; with the exception of Cataulax eximius (Stål, 1860) which has a point of occurrence on the border between Bahia and Minas Gerais, the other species do not cross the Rio Doce. Various studies infer the presence of a possible vicariant biogeographic barrier, or primary barrier to gene flow, associated with the formation of the hydrographic basin of the Rio Doce. Reference is made to this barrier in various phylogeographic studies of vertebrates, with regard to species of lizards (Gekkonidae), birds (Dendrocolaptidae) and rodents (Sigmodontinae) (Pellegrino et al., 2005; CABAnNe et al., 2008; Ventura et al., 2010) and in studies on ants (Formicidae: Ponerinae) (MARIANo et al., 2008).
The search by areas with grid-cells of $5^{\circ}$ latitudelongitude allowed the identification of Panamá as an area of endemism with different scales (Figs 7, 8), which agree with SIGRIST \& CARVALHO (2008), who associated this area with panbiogeographic nodes previously recognized by Croizat (1958). Biogeographic nodes may be interpreted as areas of great importance in the history of diversification of the taxa, and may represent the limit of ancestral biotas (CRISCI et al., 2003).

The portions to the west of areas 6 and 8 overlap the provinces identified by NAVARRo et al. (2007), Coastal and Andes mountain ranges, which are related and are sisters of the Guyana Shield endemic area.

The areas of endemism 9 and 10 possess three shared grid-cells due to the presence of Thyanta xerotica Rider, 1991 and Serdia ruckesi Thomas \& Rolston, 1985 in both areas, but area 9 is more related to the Andean region and grouping 10 to the Amazonian region. Morrone (2004b) discussed the hybrid character of the biota of the South American transition zone, the presence of a biogeographic node in the Puna province, and the relations with Neotropical and Andean elements. Despite the relative spatial congruence of areas 9, 10 and 11, they should be interpreted as distinct areas, because of the 12 species that comprise area 11 , two species are shared with area 9, two with area 10 , and one with both areas, making seven species exclusive to area 11.

Area 15 differs from area 14 by including portions to the northeast of the Pampa, the south of the Puna and northern regions of the Caatinga provinces, with limits similar to those of the Neotropical region southeast component, proposed by AMORIM \& PiREs (1996).

The Amazonian region has been traditionally treated as a historical unit, assuming that the biotic elements share a common history (see NIHEI, 2008), and was identified as a single area in the area of consensus 18 (Fig. 19). However, areas of consensus 14, 15 and 16 (Figs. 15-17) demonstrate that the southeastern portion of Amazonia share elements with the Chacoan and Paraná subregions, as proposed by NiHEI \& CARVALHo (2007) and Sigrist \& CARVALHO (2009). The distribution data of the taxa employed in the analysis are scarce for the Amazonian region, where they are restricted to the bank of the rivers and traditionally sampled areas. This leads to large portions of land without data of occurrence for any taxon, which could have made it impossible to define areas with greater support of endemic species. The initial groupings that gave rise to the consensus shown in area 18 vary considerably with respect to their composition of species and geographic position. The distribution data of Pentatomidae, analyzed here, did not allow us to infer with certainty if the evolution of the family in the Amazonian region corroborates a single area sensu Morrone (2006) or as a hybrid area (two Amazonias) sensu AMORIM \& PIRES (1996).

The analyses were sensitive to the identification of areas of endemism in different scales in the Atlantic Forest (Figs. 7; 14-18), which can be related to hierarchical pattern of endemism (EsPINOSA-Organista et al., 2001; Silva et al., 2004; Sigrist \& CARvalho, 2008). These groupings may indicate a possible division of the Atlantic Forest into different components of endemism. 
The distribution data of the taxa studied, with different units of analysis ( $5^{\circ}$ and $2.5^{\circ}$ latitude-longitude), did not allow the identification of individual areas of endemism for the Cerrado and Caatinga provinces. Area 17 was the only area of endemism obtained, which includes the whole Caatinga province; however, the Caatinga was not identified as an isolated area of endemism in any of the analyses performed in this study. The fact of the Caatinga being part of area 17 is probably an artifact of the method used, related to the size of gridcells employed. The methodology used in the detection of areas of endemism is especially sensitive to the lack of data in the regions studied (generally due to the missing samples), where the spatial discontinuity produced by this lack of information decreases the probability of occurrence of sympatry among the species, thereby modifying the patterns that may be encountered (CASAGRANDA et al., 2009).

Using a grouping unit based on grid-cells did not appear to be efficient in the identification of insular areas of endemism. Analytical procedures based on islands or archipelagos as grouping units may be less arbitrary than that based on grid-cells, and could allow a better exploration of distribution data for insular areas.

The areas of endemism identified here should be seen as primary biogeographic hypotheses (MORRONE, 2001). The use of these areas in studies of cladistic biogeography should consider proposals based on results obtained for other taxa. MoRRONE (2009) proposed an approach called evolutionary biogeography, which aims to integrate methods frequently employed in different biogeographic analyses. The search for areas of endemism and for generalized tracks (resulting from panbiogeographic analyses) is defined as the first step in identifying groupings of taxa integrated in a spatialtemporal manner, called biotic components. The second step is the test of the relationships between the biotic components, based on the inclusion of the cladistic relationships of taxa and their distribution areas.

The inclusion of cladistic data in testing areas of endemism makes possible to use different units in the substitution of terminals in cladograms, which can be useful in choosing of resultant areas from analyses of endemism, as in the case of overlapping areas or with species in common (see Nihei \& CARVALHo, 2007). The selection of conflicting areas of endemism can be based on the congruence with the general area cladograms of the taxa analyzed. Perhaps more important than choosing areas of endemism with greater scores of endemism, would be to find areas (develop a procedure that allows choosing areas) with greater congruence with the phylogenetic data employed in biogeographic analyses, this procedure will allow (with the objective of) formulating secondary biogeographic hypotheses.

Pentatomidae distribution data has received little attention over the last decades. Despite the increasing number of works using cladistic, there is a lack of hypotheses about the distribution pattern of the group. Consistent hypotheses for Pentatomidae evolution in the Neotropical region depend on the accuracy of the units employed in the analyses, which studies of historical biogeography are represented by areas of endemism. The present study is the first to use an explicit methodology for analyzing the patterns of endemism of this family in the Neotropical region. The areas of endemism recognized here need to be refined, in order to obtain higher spatial resolution, by the inclusion of new taxa, or increase in distribution data with new samples, or even with the use of other analytical tools (e.g. panbiogeography).

Acknowledgments. We gratefully acknowledge the reviewers Dr. Silvio Nihei (USP) and Juan J. Morrone (UNAM) whose suggestions helped to improve the manuscript. We are grateful to Luciano A. Moura (UFRGS) for their helpful comments on the manuscript and Dr. A. Leyva for his assitence with the English translation. A. F. acknowledge financial support from grants of postdoctoral fellowship financed by the Coordenação de Aperfeiçoamento de Pessoal de Nivel Superior (CAPES, PNPD - 2282/09); A. P., C. F. S. and J. G. acknowledge the grant support of Conselho Nacional de Desenvolvimento Científico e Tecnológico (CNPq).

\section{REFERENCES}

Amorim, D. S. \& Pires, M. R. S. 1996. Neotropical biogeography and a method for maximum biodiversity estimation. In: BICUDO, C. E. M. \& Menezes, N. A. eds. Biodiversity in Brazil: a first approach. São Paulo, CNPq. p. 183-219.

Barcellos, A. \& Grazia, J. 2003a. Cladistic analysis and biogeography of Brachystethus Laporte (Heteroptera, Pentatomidae, Edessinae). Zootaxa 256:1-14.

2003b. Revision of Brachystethus (Heteroptera, Pentatomidae, Edessinae). Iheringia, Série Zoologia, 93(4):413-446.

Biondi, M. \& D'Alessandro, P. 2006. Biogeographical analysis of the flea beetle genus Chaetocnema in the Afrotropical region: distribution patterns and areas of endemism. Journal of Biogeography 33:720-730.

Cabanne, G. G.; D'Horta, F. M.; Sari, E. H. R.; Santos, F. R. \& MiYAKI, C. Y. 2008. Nuclear and mitochondrial phylogeography of the Atlantic forest endemic Xiphorhynchus fuscus (Aves: Dendrocolaptidae): Biogeography and systematics implications. Molecular Phylogenetics and Evolution 49(3):760-773.

Carine, M. A.; Humphries, C. J.; Guma, I. R. \& Alfredo, J. 2009. Areas and algorithms: evaluating numerical approaches for the delimitation of areas of endemism in the Canary Islands archipelago. Journal of Biogeography 36(4):593-611.

CAsagranda, D. M.; Roig-JuñEnt, S. \& Szumik, C. 2009. Endemismo a diferentes escalas espaciales: un ejemplo con Carabidae (Coleoptera: Insecta) de América del Sur austral. Revista Chilena de Historia Natural 82(1):17-42.

Cavieres, L. A.; Arroyo, M. K. T.; Posadas, P.; Marticorena, C.; Matthei, O.; Rodríguez, R.; Soueo, F. A. \& Arancio, G. 2002. Identification of priority areas for conservation in an arid zone: application of parsimony analysis of endemicity in the vascular flora of the Antofagasta region, Northern Chile. Biodiversity and Conservation 11(7):1301-1311.

Costa, L. P. \& Leite, Y. L. R. 2000. Biogeography of South American forest mammals: endemism and diversity in the Atlantic Forest. Biotropica 32(4b):872-881.

CRIA. 2007. Species Link (GeoLoc). Available at: <http:// splink.cria.org.br/geoloc >. Accessed on: 10.2008.

Crisci, J. V.; Katinas, L. \& Posadas, P. 2003. Historical biogeography: an introduction. Cambridge, Harvard University. 250p.

Croizat, L. 1958. Panbiogeography: vol 1 \& 2. Caracas, Published by the author. $881 \mathrm{p}$.

1964. Space, Time, Form: the biological synthesis. Caracas, Published by the author. $676 \mathrm{p}$.

Espinosa, D.; Aguilar, C. Z. \& Escalante, T. E. 2001. Endemismo, áreas de endemismo y regionalización biogeográfica. In: Llorente-Bousquets, J. \& Morrone, J. J. eds. Introducción a la biogeografía en Latinoamérica: teorías, conceptos, métodos y aplicaciones. Ciudad de México, Facultad de Ciencias UNAM. p. 31-37. 
Falling Rain Genomics 2007. Global Gazetteer v. 2.1 19962006. Available at: <http://www.fallingrain.com/world/>. Accessed in: 10.2008.

Fernandes, J. A. M. \& Grazia, J. 2006. Revisão do gênero Antiteuchus Dallas (Heteroptera, Pentatomidae, Discocephalinae). Revista Brasileira de Entomologia 50(2): $165-231$

Fortes, N. D. F. DE \& Grazia, J. 2000. Novas espécies do gênero Rio (Heteroptera, Pentatomidae). Iheringia, Série Zoologia, (88):67-102.

Fortes, N. D. F. DE \& Grazia, J. 2005. Revisão e análise cladística de Serdia Stål (Heteroptera: Pentatomidae: Pentatomini). Revista Brasileira de Entomologia 49(3):294-339.

GLosk. 2008. Available at: 〈http://www.glosk.com/>. Accessed on: 06.2008 .

Goldani, A. \& Carvalho, G. S. 2003. Análise de parcimônia de endemismo de cercopídeos neotropicais (Hemiptera, Cercopidae). Revista Brasileira de Entomologia 47(3):437-442.

Goldani, A.; Ferrari, A.; Carvalho, G. S. \& Creão-Duarte, A. J. 2002. Análise de parcimônia de endemismos de membracídeos neotropicais (Hemiptera, Membracidae, Hoplophoriorini). Revista Brasileira de Zoologia 19(Supl.2):187-193.

Goldman, E. A. \& Moore, R. T. 1945. The biotic provinces of México. Journal of Mammalogy 26(4):347-360.

Goloboff, P. 2008. NDM version 2.6. Provided by author. Available at: <http://www.zmuc.dk/public/phylogeny>. Accessed on: 06.2008.

Grazia, J. 1978. Revisão do gênero Dichelops Spinola, 1837 (Heteroptera, Pentatomidae, Pentatomini). Iheringia, sér. Zool. (53):1-119.

1980. Revisão do gênero Pallantia Stål, 1862 (Heteroptera, Pentatomidae). Revista Brasileira de Entomologia 24(1):15-27.

1997. Cladistic analysis of the Evoplitus genus group of Pentatomini (Heteroptera: Pentatomidae). Journal of Comparative Biology 2(1):43-48.

Grazia, J. \& Becker, M. 1995. Adevoplitus, a new genus of neotropical Pentatomini (Heteroptera, Pentatomidae). Journal of the New York Entomological Society 103(4):386-400.

Grazia, J.; Becker, M. \& Thomas, D. B. 1994. A review of the genus Pseudevoplitus Ruckes (Heteroptera: Pentatomidae), with the description of three new species. Journal of the New York Entomological Society 102(4):442-455.

Grazia, J.; CAmpos, L. A. \& Becker, M. 1993. Revisão do gênero Evoplitus Amyot \& Serville (Heteroptera, Pentatomidae, Pentatomini). Revista Brasileira de Entomologia 37(1):41-48. 2000. Revision of Cataulax Spinola, with Architas Distant as a new synonymy (Heteroptera: Pentatomidae: Discocephalini). Anais da Sociedade Entomológica do Brasil 29(3):475-488.

Grazia, J.; Campos, L. A.; Greve, C. \& Rocha, F. S. 2002. Notas sobre Pseudevoplitus (Heteroptera, Pentatomidae) e descrição de duas espécies novas. Iheringia, sér. Zool. 92(1):53-61.

Grazia, J. \& Fortes, N. D. F. DE 1995. Revisão do gênero Rio Kirkaldy, 1909 (Heteroptera, Pentatomidae). Revista Brasileira de Entomologia 39(2):409-430.

Grazia, J.; Schwertner, C. F. \& Ferrari, A. 2006. Description of five new species of Chinavia Orian (Hemiptera, Pentatomidae, Pentatominae) from Western and Northwestern South America. In: RabiTsCH, W. ed. Hug the bug for love of true bugs, Festschrift zum 70 Geburtstag von Ernst Heiss: Kataloge der Oberösterreichischen Landesmuseen. Denisia, Linz 19:423-434.

Hausdorf, B. 2002. Units in biogeography. Systematic Biology 51(4):648-652.

Henderson, I. M. 1991. Biogeography without area? Australian Systematic Botany 4(1):59-71.

HovenKAMP, P. 1997. Vicariance events, not areas, should be used in biogeographical analysis. Cladistics 13(1-2):67-79.

Humphries, C. J. \& Parenti, L. R. 1999. Cladistic Biogeography. 2ed. Oxford, Oxford University. 187p.

Laffan, S. W. \& Crisp, M. D. 2003. Assessing endemism at multiple spatial scales, with an example from the Australian vascular flora. Journal of Biogeography 30(4):511-520.
Linder, H. P. 2001. On areas of endemism, with an example from the African Restionaceae. Systematic Biology 50(6):892-912

Mariano, C. S. F.; Pompolo, S. G.; Barros, L. A. C.; MarianoNeto, E.; Campiolo, S. \& Delabie, J. H. C. 2008. A biogeographical study of the threatened ant Dinoponera lucida Emery (Hymenoptera: Formicidae: Ponerinae) using a cytogenetic approach. Insect Conservation and Diversity 1(3): 161-168.

Marino-Pérez, R.; Brailovsky, H. \& Morrone, J. J. 2007. Análisis panbiogeográfico de las especies mexicanas de Pselliopus Bergroth (Hemiptera: Heteroptera: Reduviidae: Harpactorinae). Acta Zoológica Mexicana 23(2):77-88.

McPherson, J. E. \& McPherson, R. M. 2000. Stink bugs of economic importance in America North of Mexico. New York, CRC. 272p.

Morrone, J. J. 1994. On the identification of areas of endemism. Systematic Biology 43(3):438-441.

2001. Homology and areas of endemism. Diversity and Distributions 7(6):297-300.

2004b. La zona de transición Sudamericana: caracterización y relevancia evolutiva. Acta Entomologica Chilena 28(1):41-50.

2006. Biogeographic areas and transition zones of Latin America and the Caribbean Islands based on panbiogeographic and cladistic analyses of the entomofauna. Annual Review of Entomology 51:467-494.

2009. Evolutionary biogeography: An integrative approach with case studies. New York, Columbia University. $301 \mathrm{p}$.

Morrone, J. J. \& Coscarón, M. C. Del. 1996. Distributional patterns of the American Peiratinae (Heteroptera: Reduviidae). Zoologische Mededelingen 70(1):1-15.

Morrone, J. J. \& Escalante, T. 2002. Parsimony analysis of endemicity (PAE) of Mexican terrestrial mammals at different areas units: when size matters. Journal of Biogeography 29:1-10.

Morrone, J. J.; Mazzucconi, S. A. \& Bachmann, A. O. 2004 Distributional patterns of Chacoan water bugs (Heteroptera: Belostomatidae, Corixidae, Micronectidae and Gerridae). Hydrobiologia 523(1-3):159-173.

Navarro, J. C.; Liria, J.; Piñango, H. \& Barrera, R. 2007. Biogeographic area relationships in Venezuela: a parsimony analysis of Culicidae - Phytotelmata distribution in National Parks. Zootaxa 1547:1-19.

Nelson, G. \& Platnick, N. 1981 Systematics and biogeography, cladistics and vicariance. New York, Columbia University. $567 \mathrm{p}$

NiHeI, S. S. 2008. Dynamic endemism and 'general' biogeographic patterns. Biogeografía: Bulletin of the Systematic and Evolutionary Biogeographical Association 3:2-6.

Nihei, S. S. \& Carvalho, C. J. B. DE 2007. Systematics and biogeography of the Neotropical genus Polietina Schnabl \& Dziedzicki (Diptera, Muscidae): neotropical areas relationships and Amazonia as a composite area. Systematic Entomology 32(3):477-501.

Panizzi, R. A.; McPherson, J. E.; James, D. G.; Javahery, M. \& McPherson, R. M. 2000. Stink bugs (Pentatomidae). In: Schaefer, C. \& Panizzi, R. A. eds. Heteroptera of economic importance. Boca Raton, CRC Press. p. 421-474.

Pellegrino, K. C. M.; Rodrigues, M. T.; Waite, A. N.; Morando, M.; Yassuda, Y. Y. \& Sites JR. J. W. 2005. Phylogeography and species limits in the Gymnodactylus darwinii complex (Gekkonidae, Squamata): genetic structure coincides with river systems in the Brazilian Atlantic Forest. Biological Journal of the Linnean Society 85(1):13-26.

Platnick, N. I. 1991. On areas of endemism. Australian Systematic Botany 4(1):11-12.

RIDER, D. A. 1986. Description of the male of Acrosternum istum (Hemiptera: Pentatomidae). The Florida Entomologist 69(1):229-231.

1992. Revision of Arocera Spinola, with the description of two new species (Heteroptera: Pentatomidae). Journal of the New York Entomological Society 100(1):99-136.

2009. Pentatomoidea Home page - North Dakota State University. Available at: <http://www.ndsu.edu/ndsu/ 
rider/Pentatomoidea/Researchers/Rider_David.htm>. Accessed in: 06.2009 .

Rider, D. A. \& Chapin, J. B. 1991. Revision of the genus Thyanta Stål, 1862 (Heteroptera: Pentatomidae) I. South America. Journal of the New York Entomological Society 99(1):1-77.

1992. Revision of the genus Thyanta Stål, 1862 (Heteroptera: Pentatomidae) II. North America, Central America and the West Indies. Journal of the New York Entomological Society 100(1):42-98.

Rider, D. A. \& Rolston, L. H. 1987a. Three new species of Acrosternum Fieber, subgenus Chinavia Orion, from Mexico (Hemiptera: Pentatomidae). Journal of the New York Entomological Society 94(3):416-423.

1987b. Review of the genus Agroecus Dallas, with the description of a new species (Heteroptera: Pentatomidae). Journal of the New York Entomological Society 95(3): 428-439.

Rolston, L. H. 1983. A revision of the genus Acrosternum Fieber, subgenus Chinavia Orian in the Western Hemisphere (Hemiptera, Pentatomidae, Pentatomini). Journal of the New York Entomological Society 91:97-176.

Rovito, M. S.; Arroyo, M. T. K. \& Pliscoff, P. 2004. Distributional modelling and parsimony analysis of endemicity of Senecio in the Mediterranean-type climate area of Central Chile. Journal of Biogeography 31(10):1623-1636.

Schwertner, C. F. 2005. Filogenia e classificação do grupo Nezara Amyot \& Serville, 1843 (Hemiptera, Pentatomidae, Pentatominae). 253p. Tese (Doutorado em Biologia Animal). Porto Alegre, Universidade Federal do Rio Grande do Sul. 253p. (unpublished)
Schwertner, C. F. \& Grazia, J. 2006. Descrição de seis novas espécies de Chinavia (Hemiptera, Pentatomidae, Pentatominae) da América do Sul. Iheringia, Série Zoologia, 96(2):237-248.

Sigrist, M. S. \& Carvalho, C. J. B. 2008. Detection of areas of endemism on two spatial scales using parsimony analysis of endemicity (PAE): the Neotropical region and the Atlantic Forest. Biota Neotropica 8(4):33-42.

2009. Historical relationships among areas of endemism in the tropical South America using Brooks Parsimony Analysis (BPA). Biota Neotropica 9(4):79-90.

Silva, J. M. C.; Souza, M. C. \& Castelletti, C. H. M. 2004. Areas of endemism for passerine birds in the Atlantic forest, South America. Global, Ecology and Biogeography 13(1):85-92.

Szumik, C. A. \& Goloboff, P. A. 2004. Areas of endemism: an improved optimality criterion. Systematic Biology 53(6): $968-977$.

Szumik, C. A.; Cuezzo, F.; Goloboff, P. A. \& Chalup, A. E. 2002. An optimality criterion to determine areas of endemism. Systematic Biology 51(5):806-816

Thomas, D. B. 2000. Pentatomidae (Hemiptera). In: Llorente, J. E.; Gonzalez, E. \& Papavero, N. eds. Biodiversidad, taxonomía y biogeografía de artrópodos de México: hacia un síntesis de su conocimiento. Ciudad de México, Universidad Nacional Autónoma de México. p. 335-352.

Ventura, K.; Silva, M. J. J. \& Yonenaga-Yassuda, Y. 2010 Thaptomys Thomas 1915 (Rodentia, Sigmodontinae, Akodontini) with karyotypes $2 \mathrm{n}=50, \mathrm{FN}=48$, and $2 \mathrm{n}=52$, $\mathrm{FN}=52$ : two monophyletic lineages recovered by molecular phylogeny. Genetics and Molecular Biology 33(2):256-261. 